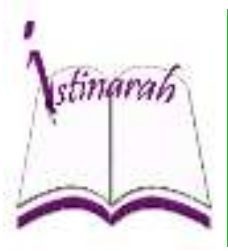

Istinarah: Riset Keagamaan, Sosial dan Budaya, Vol 1 (2), Desember 2019

ISSN : --------- (Print) .............. (Online $)$

Tersedia online di http://ecampus.iainbatusangkar.ac.id/ojs/index.php/istinarah/index

\title{
Penafsiran Ayat-Ayat Zakat Oleh Maulana Muhammad Zakariyya Al-Kandahlawi dalam Buku Fadhilah Sedekah
}

\author{
Muhammad Sofian *) \\ Institut Agama Islam Negeri \\ Batusangkar \\ Sumatera Barat, Indonesia \\ E-mail: sofianm314@gmail.com
}

\section{Syamsuwir}

Institut Agama Islam Negeri

Batusangkar.

Sumatera Barat, Indonesia

E-mail:

syamsuwir@iainbatusangkar.ac.id

\section{Dapit Amril}

Institut Agama Islam Negeri

Batusangkar.

Sumatera Barat, Indonesia

E-mail:

dapitamril@iainbatusangkar.ac.id

*) Corresponding Author

\begin{abstract}
Abstrak: Penelitian ini berdasarkan bahwa Maulana Muhammad Zakariyya Al-Kandahlawi adalah seorang ahli hadits, akan tetapi ia menafsirkan ayat-ayat tentang zakat dalam buku Fadhilah Sedekah. Tujuan penelitian ini adalah untuk menjelaskan dan mendeskripsikan bagaimana penafsiran Maulana Muhammad Zakariyya Alkandahlawi terhadap ayat zakat. Jenis penelitian adalah penelitian kepustakaan (library research). Analisis yang digunakan dalam penelitian ini mengacu pada content analisis. Hasil penelitian ini menunjukkan bahwa: 1) Zakat memiliki dua kedudukan penting yaitu: Pertama Bagi muzakki, bagaimana dia bisa menjadi tuan terhadap hartanya. Kedua pentingnya zakat bagi mustahiq ialah memperbaiki ekonomi umat. 2) Keutamaan bagi muzakki yaitu: membersihkan dosa, mengangkat derajat, menjadi orang ikhlas, dan menyuburkan akhlak tepuji. 3) Acaman diberikan kepada orang yang tidak menunaikan zakat ada 2 yaitu. Ancaman di dunia dan di akhirat.
\end{abstract}

Abstract: This research is based on that Maulana Muhammad Zakariyya Al-Kandahlawi is a hadith expert, but he interprets verses about zakat in the book Fadhilah Alms. The purpose of this study is to explain and describe how the interpretation of Maulana Muhammad Zakariyya Al-kandahlawi on the verse of zakat. This type of research is library research. The analysis used in this study refers to content analysis. The results of this study indicate that: 1) Zakat has two important positions, namely: First For muzakki, how can he be the master of his wealth. Secondly the importance of zakat for mustahiq is to improve the economy of the people. 2) The virtues for muzakki are: cleansing sins, raising degrees, being sincere, and cultivating good morals. 3) Threats are given to people who do not pay zakat there are 2 namely. There are two threats in the world, namely: the punishment that comes directly from Allah and the punishment that is entrusted by Allah Almighty through devout Muslim rulers. Threats or punishment in the afterlife, which is ironed with assets that are not tapped, and poisonous snakes will wrap around their necks.

Kata Kunci : Penafsiran, Keutamaan, Ancaman, Zakat 


\section{PENDAHULUAN}

Menafsirkan Al-Quran berarti berupaya untuk menjelaskan dan mengungkapkan maksud dari kandungan Al-Quran. Oleh karena itu obyek kajian tafsir adalah Al-Quran, karena ia merupakan sumber pertama ajaran agama Islam sekaligus petunjuk bagi manusia, maka penafsiran terhadap Al-Quran bukan hanya menjadi suatu hal yang diperbolehkan, bahkan lebih dari itu, bagi orang-orang yang memenuhi kualifikasi untuk melakukannya (Hasan, 1997:155).

Zakat merupakan suatu bentuk kepedulian sosial dengan cara membelanjakan hartanya di jalan Allah Swt, zakat tersebut adalah anjuran dari Allah Swt yang terdapat dalam Al-Quran maupun Hadits Rasulullah Saw. Untuk itu mengkaji zakat tersebut untuk mengingatkan tentang harta yang dimiliki merupakan titipan dari Allah Swt yang nantinya dimintai pertanggung jawaban di akhirat kelak. Oleh karena itu, membahas topik ini merupakan suatu hal yang sangat aktual dan menarik untuk dikaji. Islam menganjurkan untuk membelanjakan harta yang dimiliki dengan cara berzakat terhadap sesama umat muslim. Namun, tentu tujuan yang paling utama dari zakat adalah untuk mendekatkan diri kepada Allah Swt, zakat adalah apa yang engkau berikan pada jalan Allah Swt kepada orang fakir.

Zakat termasuk kedalam sedekah yang wajib, menurut Samr Al-Jam'an bahwa, sedekah adalah harta yang dinafkahkan dengan mengharapkan pahala dari Allah Swt. Sedekah terbagi menjadi yang wajib dan yang sunnah. Dalam penggunaan istilah syariat, yang wajib disebut dengan lafazh zakat, dan yang sunnah dengan lafazh sedekah. Disebut dengan istilah sedekah, karena diambil dari pengertian adanya ketulusan, baik dalam perbuatan, ucapan, maupun keyakinan (al-Jam'an, 2014:11).

Maulana Muhammad Zakariyya Al-Kandahlawi merupakan sosok alim ulama yang telah terkenal di kalangan Jamaah Tabligh. Ulama yang telah banyak mengarang kitab-kitab, salah satu kitab tersebut yang menjadi pembahasan skripsi ini ialah kitab Fadhilah Sedekah, yang menjadi rujukan bacaan Jamaah Tabligh di saat mereka melakukan ta'lim di masjid/mushala maupun di rumah, 
mereka membacakan kitab Fadhilah Sedekah ini setiap hari, walaupun mereka telah selesai membacakannya sampai akhir, mereka tetap mengulangnya kembali. Mereka menjadikan buku Fadhilah Sedekah sebagai panduan dalam beramal dan penyemangat untuk melaksanakan amalan-amalan yang sesuai dengan Rasulullah Saw.

Berdasarkan uraian di atas, peneliti tertarik untuk melihat dan menggali serta memahami bagaimana penafsiran Maulana Muhammad Zakariyya Al-Kandahlawi terhadap ayat-ayat tentang penting (surah AlBaqarah: 43), keutamaan (surah AlA'raf: 159 dan Ar-Rum: 39) dan ancaman bagi yang tidak menunaikan zakat (At-Taubah: 34-35 dan AliImron: 180) dalam buku Fadhilah Sedekah

\section{METODE}

Dalam penelitian ini, penulis menggunakan jenis penelitian kepustakaan (Library research), yaitu teknik pengumpulan data dengan mengadakan studi penelaahan terhadap buku-buku, literatur-literatur, catatan-catatan, dan laporan-laporan yang ada hubungannya dengan masalah yang dipecahkan (Nazir, 2003: 27). Studi pustaka dalam penelitian skripsi ini dapat berisikan teori dan konsep-konsep yang akan dipakai oleh peneliti untuk menginterprestasikan data. Penelitian ini fokus pada mengkaji aspek-aspek yang mengenai penting, keutamaan, dan ancaman bagi yang tidak zakat yang terdapat dalam penafsiran Maulana Muhammad Zakariyya AlKandahlawi dalam buku Fadhilah Sedekah. Penelitian kepustakaan ini juga disebut dengan serangkaian kegiatan yang berkenaan dengan metode pengumpulan data pustaka, membaca dan mencatat serta mengolah bahan penelitian yang ada di perpustakaan (Zed, 2004: 3-5).

Tujuan penelitian penelitian ini pada dasarnya adalah untuk menjelaskan dan mendeskrifsikan tentang: Pertama, penafsiran pentingnya zakat oleh Maulana Muhammad Zakariyya AlKandahlawi. Kedua, penafsiran keutamaan zakat oleh Maulana Muhammad Zakariyya AlKandahlawi. Ketiga, penafsiran ancaman bagi yang tidak menunaikan zakat oleh Maulana Muhammad 
Zakariyya Al-kandahlawi.

Penelitian fokus kepada bahanbahan yang terdapat pada perpustakaan. Berdasarkan hal itu peneliti akan melakukan penelitian ini di perpustakaan IAIN Batusangkar dan di tempat lain dimana sumber bisa peneliti temukan.

Sumber data adalah orang/ subjek dan objek yang dijadikan sumber untuk memberikan informasi tentang situasi dan kondisi latar penelitian (Moleong, 2006: 90). Pertama, Sumber data Primer

Sumber data primer (utama) yang penulis gunakan dalam penelitian ini adalah Buku Fadhilah Sedekah tulisan Maulana Muhammad Zakariyya AlKandahlawi. Kedua, Sumber data Sekunder adalah hasil-hasil penelitian atau tulisan-tulisan para peneliti atau teoritis, dan beberapa kitab tafsir atau buku seperti Kitab Tafsir Al-Quranul Madjid An-Nur karangan Teungku Muhammad Hasbi Ash-Siddieqy, Tafsir Ibnu Katsir dalam buku Kemudahan dari Allah Ringkasan Tafsir Ibnu Katsir yang diringkas oleh Muhammad Nasib Ar-Rifa`i dan buku Kaifa Nata`amal Ma`a Al-Quran alKarim karangan Yusuf al-Qardhawi.
Teknik pengumpulan data yang penulis lakukan yaitu dengan cara mengumpulkan/menghimpun ayatayat tentang penting, keutamaan, dan ancaman bagi yang tidak zakat dalam buku Fadhilah Sedekah. Kemudian ayat-ayat tersebut diklasifikasikan, selanjutnya penulis mengidenfikasikan ayat-ayat tersebut. Kemudian diolah dan digali penafsirannya dengan mengacu kepada kitab tafsir yang ada (Prasetiyo, 2006: 50).

Teknik analisis data dalam penelitian merupakan bagian penting dalam proses penelitian karena dengan analisis inilah, data yang ada akan tampak manfaatnya, terutama dalam memecahkan masalah penelitian dan mencapai tujuan akhir penelitian (Mahmud, 2011: 189). Data yang telah diperoleh, kemudian diolah dengan menggunakan metode analisis isi (content analisis), yaitu teknik yang biasa digunakan dalam penelitian kepustakaan, yakni dengan cara menganalisis terhadap berbagai sumber informasi yang telah didapat termasuk bahan cetak (buku, artikel, koran, majalah, dan sebagainya) (Prasetiyo, 2006: 60).

Analisis yang digunakan dalam 
penelitian ini mengacu pada aplikasi metode penafsiran al-Quran. Metode analisis yang penulis digunakan adalah metode tafsir semi maudhu $i$ (tematik). Tafsir maudhu $i$ adalah menjelaskan ayat yaitu menafsirkan ayat-ayat AlQuran berdasarkan tema tertentu. Penulis menghimpun ayat-ayat zakat yang terdapat dalam buku Fadhilah Sedekah (Zaini dan Andy, 2015: 105).

Berdasarkan metode analisis data yang dijelaskan di atas, dapat disimpulkan prosesnya berjalan sebagai berikut: Pertama, menghimpun sumber-sumber data yang berkaitan dengan pembedahan buku dan kitab- kitab mengenai "Penafsiran Ayat-Ayat Zakat oleh Maulana Muhammad Zakariyya AlKandahlawi dalam Buku Fadillah Sedekah”. Kedua, membaca, menelaah dan mencatat sumbersumber data yang telah dikumpulkan. Ketiga, membahas masalah-masalah yang diajukan. Keempat, menarik kesimpulan.

Berdasarkan penjelasan di atas, dapat diungkapkan bahwa seluruh hasil penelitian didapatkan dari bahanbahan yang ada di perpustakaan, baik Al-Quran, buku-buku tafsir dan buku yang berkaitan dengan penting, keutamaan, ancaman bagi yang tidak menunaikan zakat. Kemudian bahan yang sudah ada dikumpulkan untuk diolah melalui metode yang telah ditetapkan, dan dianalisis serta dikembangkan dengan bahan penulis, sehingga diharapkan dapat berkesinambungan antara data yang didapatkan dengan tujuan penelitian yang diinginkan.

\section{HASIL DAN PEMBAHASAN}

Berdasarkan hasil penelitian terkait dengan penafsiran ayat-ayat tentang penting, keutamaan, ancaman bagi yang tidak menunaikan zakat yaitu sebagai berikut ini:

Satu: pentingnya menunaikan zakat dalam surah Al-Baqarah: 43

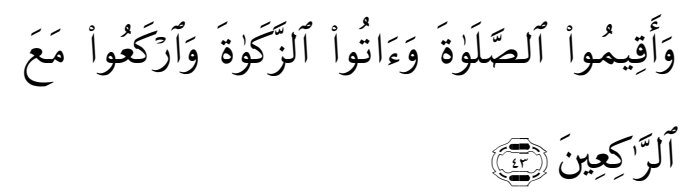

Artinya: Dan dirikanlah shalat, tunaikanlah zakat dan rukulah beserta orang-orang yang ruku

Penafsiran Maulana Muhammad Zakariyya Al-Kandahlawi dalam Buku Fadhilah Sedekah Al-Quran surah AlBaqarah ayat 43 menjelaskan bahwa amal ibadah dalam Islam terbagi 
menjadi dua bagian, yakni amalan yang bersifat lahiriah, dan amalan batiniah. Amalan lahiriah terbagi menjadi dua bagian, yakni ibadah badani (yang dilakukan oleh tubuh), dan ibadah mali (yang dilakukan dengan harta). Itulah kategori amal secara keseluruhan. Ayat di atas telah menyebutkan masing-masing dari ketiga jenis amal tersebut. Shalat merupakan ibadah badaniah, dan zakat merupakan ibadah maliah, sedangkan khusyu' dan khudu' merupakan ibadah batiniah. Berkenaan dengan masalah tawadhu' secara batiniah, maka bergaul bersama ahli tawadhu' sangat mempengaruhi dan memberi kesan yang dalam (alKandahlawi, 2006: 253).

Dua: Keutamaan menunaikan zakat dalam Al-Quran surah Al-A'raf: 159

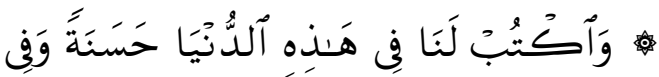

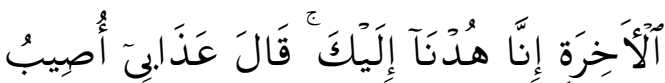

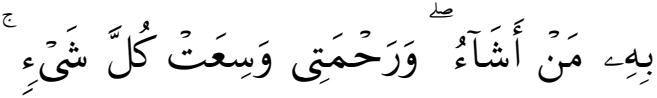

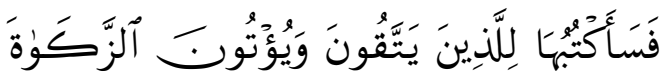

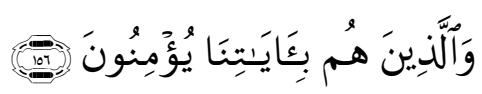

Artinya: Dan rahmat-Ku meliputi segala sesuatu, maka aku tetapkan rahmat-kut untuk orang-orang yang bertakwa, yang menunaikan zakat, dan orang-orang yang beriman kepada ayat-ayat kami.

Penafsiran Maulana Muhammad Zakariyya Al-Kandahlawi dalam Buku Fadhilah Sedekah Al-Quran surat AlA`raf: 156 menjelaskan bahwa rahmat Allah Swt di dunia meliputi setiap orang, baik orang shalih maupun jahat. Akan tetapi di akhirat, rahmat Allah Swt hanya akan diberikan kepada kepada orang-orang yang bertaqwa saja. Pada suatu ketika, seorang Arab Badui datang ke Masjid, dan setelah shalat ia berdoa, "Ya Allah, turunkan rahmat-Mu ke atasku dan Muhammad Saw, dan jangan biarkan orang lain mendapatkan bagian rahmat-Mu bersama kami. Mendengar doa orang tersebut Rasulullah Saw bersabda, "engkau telah membatasi keluasan rahmat Allah Swt", Allah Swt membagi rahmat-Nya menjadi seratus bagian. Satu rahmat telah diturunkan ke dunia dan dibagi ke seluruh dunia. Oleh karena itu, seluruh makhluk baik jin, manusia, ataupun binatang saling menyayangi (kepada anak-anak mereka, sanak keluarga, dan yang lain).

Sungguh suatu hal yang 
menggembirakan betapa ibu begitu sayang kepada anak-anaknya, sampaisampai sedikit saja anak mengalami kesusahan, seorang ibu akan merasa tidak tenang. Seorang ayah pun akan merasa sedih apabila anak-anaknya mengalami suatu musibah. Demikian pula terhadap kaum kerabat, keluarga, suami istri, atau orang lain akan merasa kasihan apabila melihat yang lain dalam kesusahan. Semua ini merupakan perwujudan dari rahmat Allah Swt yang diletakkan di dalam hati makhluk-Nya. Jika rahmat seluruh dunia ini dikumpulkan menjadi satu, maka jumlahnya hanya satu persen dari rahmat Allah Swt, sedangkan rahmat Allah Swt yang lain, yakni yang berjumlah sembilan puluh sembilan masih tersimpan di sisi-Nya. Betapa tidak malu dan betapa zhalimnya jika ada orang yang tidak menghiraukan printah Allah Swt Yang Maha Penyayang dan maha pengasih. Apabila ada seorang ibu yang sangat sayang kepada anaknya, kemudian anak-anaknya tidak menghiraukan perintahnya, maka betapa sedihnya hati ibu itu. Padahal kasih sayang seorang ibu tidak ada apa-apanya jika dibandingkan dengan kasih sayang
Allah Swt. Oleh karena itu, dapat dibayangkan bagaimana jika kita melalaikan perintah-Nya (alKandahlawi, 2006:254-255).

Berdasarkan uraian penafsiran Maulana Muhammad Zakariyya AlKandahlawi tersebut penulis memahami bahwa Zakariyya tidak secara langsung menyebutkan katakata zakat dalam penafsirannya, sehingga penafsirannya berkesan tidak sesuai dengan ayat tersebut, akan tetapi Zakariyya menggunakan kata taqwa karena orang yang bertaqwa pasti akan mengeluarkan zakat, maka keutamaan zakat pada ayat ini yaitu: orang yang berzakat akan mendapatkan Rahmat dari Allah Swt.

Tiga: Ancaman bagi yang tidak menunaikan zakat dalam Al-Quran surah At-Taubah: 34-35

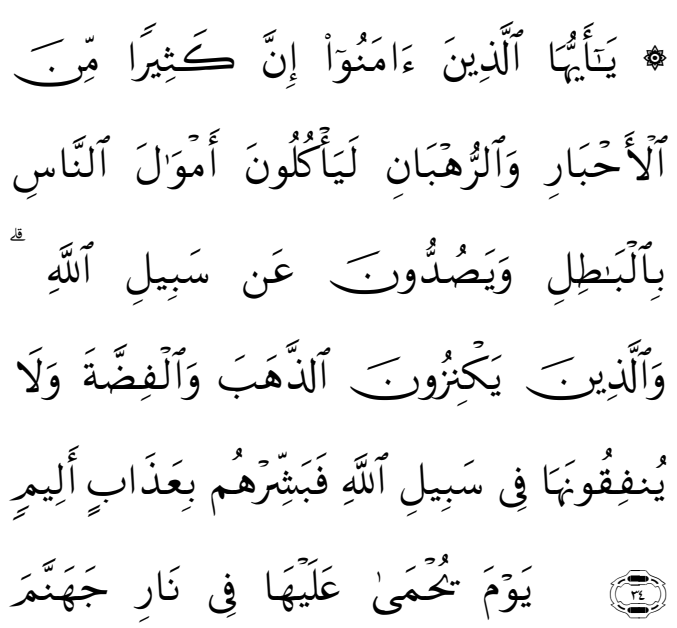




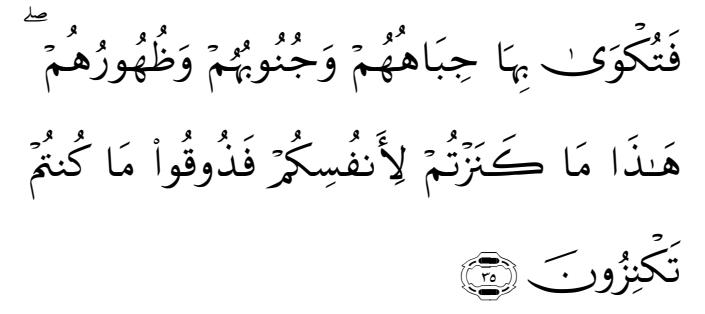

Artinya: Dan orang-orang yang menyimpan emas dan perak dan tidak menafkahkannya di jalan Allah, maka beritahukanlah kepada mereka, (bahwa mereka akan mendapat) siksa yang pedih pada hari dipanaskan emas perak itu dalam neraka Jahannam, lalu dibakar dengannya dahi mereka, lambung dan punggung mereka (lalu dikatakan) kepada mereka, "Inilah harta bendamu yang kamu simpan untuk dirimu sendiri, maka rasakanlah sekarang (akibat dari) apa yang kamu simpan itu."

Penafsiran Maulana Muhammad Zakariyya Al-Kandahlawi dalam Buku Fadhilah Sedekah, ulama telah sepakat bahwa ayat ini diturunkan berkenaan dengan masalah zakat. Adapun azab yang pedih sebagaimana yang disebutkan dalam ayat tersebut ditujukan bagi orang-orang yang tidak menunaikan zakat, sebagaimana telah dijelaskan dalam keterangan mengenai ayat tersebut. Dijelaskan bahwa bentuk azab yang disebutkan dalam ayat ini adalah bahwa hartanya akan dipanaskan lalu diseterikakan di dahi dan lambung orang tersebut. Inilah azab bagi yang tidak menunuaikan zakat, semoga Allah dengan limpahan
karunia-Nya menjaga dari azab tersebut. Disentuh dengan kawat yang dipanaskan saja tentunya merupakan penderitaan yang tidak terperikan, apalagi jika harta itu dipanaskan kemudian diseterikakan kepada orang yang tidak mau membayar zakat, tentu sangat mengerikan. Bahkan dengan menyimpan emas dan perak selama beberapa hari saja, adzab yang akan ditimpakan kepadanya sangatlah pedih (al-Kandahlawi, 2006:271).

Penafsiran Maulana Muhammad Zakariyya tersebut penulis memahami bahwa ancaman bagi yang tidak membayar zakat ialah hartanya akan dipanaskan lalu disiramkan ke dahi dan lambung orang tersebut

\section{KESIMPULAN}

Pentingnya zakat ada 2 yaitu zakat merupakan tanda bersyukur atas pemberian Allah Swt, dan zakat menimbulkan kerendahan hati pada muzakki. Pentingnya zakat bagi muzakki dan mustahiq yaitu: Pertama, pentingnya Zakat bagi Muzakki ada 3 yaitu: untuk menjadikan seorang muzakki bisa menjadi tuan terhadap hartanya Kedua, pentingnya Zakat bagi Mustahiq ada 2 yaitu: memperbaiki ekonomi umat dan 
mempersempit ketimpangan ekonomi di dalam masyarakat (mustahiq). Keutamaan Zakat menurut Maulana Muhammad Zakariyya Al-Kandahlawi ada 2 yaitu orang yang berzakat akan mendapatkan rahmat dari Allah Swt dan akan mendapatkan pahala yang lebih baik di akhirat.

Sedangkan ancaman bagi yang tidak menunaikan zakat ada dua, yaitu ancaman di dunia dan akhirat yaitu: Pertama, ancaman dan hukuman di dunia ada 2 ialah hukuman yang sifatnya langsung datang dari Allah SWT, dan hukuman yang sifatnya dititipkan Allah Swt lewat para penguasa muslim yang taat dan menjalankan hukum syariat seperti, disita Separuh Hartanya, divonis Kafir,dan dibunuh. Kedua, ancaman atau Hukuman di Akhirat yaitu diisetrika dengan harta yang tidak dizakatkan, ular berbisa akan mellilit lehernya dan mendapatkan hinaan serta murka dari Allah Swt.

\section{REFERENSI}

Hasan, M. Ali. 1997. Zakat, Pajak Asuransi dan Lembaga Keuangan. Jakarta: PT Raja rafindo Persada
al-Jam'an, Samr Bin Muhammad. 2014. Misteri Dibalik Sedekah. Judul Asli "Asraar Wa ‘Ajaa-ib Ash-Shadaqah” Jakarta: Mu-Assasah

al-Kandahlawi, Muhammad Zakariyya. 2006. Fadhilah sedekah. Judul Asli "Fadha ì Shadaqah". Terjemahan Ali Mahfudzi. Yogyakarta: Ashshaff

Mahmud. 2011. Metodelogi Penelitian Pendidikan. Bandung: Pustaka Setia

Moleong, Lexy J. 2012. Metode Penelitian Kualitatif. Bandung: Remaja Rosdakarya.

Nazir, Muhammad. 2003. Metode Penelitian. Et 5. Jakarta: Ghalia Indonesia

Prasetiyo, Irawan. 2006. Penelitian Kuantitatif dan Kualitatif. Jakarta: Diva Press

Zaini.H dan N. Andy, 2015. Ilmu Tafsir. Batusangkar: Stain Batusangkar Press.

Zed, Mestika. 2004. Metode Penelitian Kepustakaan. Jakarta: Yayasan Obor Indonesia 